\title{
Industrial Compensation Gap, Family Ownership, and Risk Preferences
}

\author{
Muhammad Ridha Jihad ${ }^{1 *}$, Vera Diyanty ${ }^{1}$ \\ ${ }^{1}$ Universitas Indonesia \\ Email: muhridhajihad@gmail.com
}

\begin{abstract}
This study aimed to provide empirical evidence about the effect of industry's gap compensation and family firm on risk preferences. This research observed 1282 data from 299 companies sample from Indonesia Stock exchange (BEI) over 2011-2015. The results show that industry's gap compensation and family firm has negative effect on risk preferences. Empirical results not show that family firm weakens negative relationship between industry's gap compensation and risk preferences. Implication of this research is the importance of standard amount of compensation to directors based on task and responsibility that is given to them. It will prevent opportunistic behavior of directors in risk-taking policies.
\end{abstract}

Type of paper: Empirical

Keywords: Industrial Compensation Gap, Family Ownership, Risk Preferences

\section{Introduction}

Bad governance in financial institutions in the US led to global crisis that hit some countries in the world in 2008 and caused Wall Street down. Indonesia experienced a similar crisis in 1998-1999. The Asian Development Bank (ADB) identified the main factor of the crisis was a weak corporate governance practices (Zhuang et al., 2000; World Bank, 2016). Thus, the crisis became a momentum in encouraging the need for corporate governance reform. Corporate governance's improvement has not been working very well. The Asean Capital Market Forum (ACMF) survey placed Indonesia at the bottom two in 2013 and 2014. Based on the survey, governance improvements in Indonesia have not been maximized (ACMF, 2015).

According to Kolb (2010), the implementation of corporate governance involves two mechanisms: internal and external (Jaiswall and Bhattacharyya, 2016). In internal mechanism, directors play an important role. The Board of Directors play a role in determining the direction, strategy, and policy of the company to achieve the company's target (KNKG, 2006). Therefore, it is necessary to make the order in overseeing and managing the activities of the board of directors. One form of order is the provision of compensation (Kolb, 2010).

Appropriate compensation can improve alignment between directors and shareholders (Faleye, 2011). Previous research found that management compensation reduces errors in the 
recording of financial statements (Efendi et al., 2007), increasing the motivation, ownership, and responsibility of directors to achieve the targets that is given by shareholders (Kini and Williams, 2012). Therefore, compensation is positively related to firm performance and value (Dey, 2008).

Inappropriate compensation will lead to three problems for the company (Kolb, 2010). First, reduce the probability of achieving the target. Second, increase the likelihood of harm policies. Third, reduce the loyalty and commitment of the directors, this will have a direct impact on the high turnover rate. Another issue will arise when the average industry compensation is benchmarked by the directors in assessing their earnings. Kale et al. (2009) mentioned that the existence of a compensation gap within an industry will lead to the motivation to move to another companies that offer better compensation packages. Coles, Li, and Wang (2012) argue that showing good performance is the good way for directors to get good compensation packages.

Huang et al. (2015) stated that a competition exists between directors to fight for the position of directors in companies that have promising compensation packages. Therefore, the directors of the company increase their risk preference to bring better performance (Kini and Williams, 2012; Kubick and Masli, 2016). The argument is in line with Coles et al. (2012) who stated that directors will increase risk preferences if compensation directors is in below of average industry compensation. The Board of Directors will increase policy making that can provide benefits and risks simultaneously for the company (Kubick and Masli, 2016). The policy can provide additional funds to develop and improve company performance. However, those policies may pose risks if they cannot generate results as expected (Ross et al., 2010).

According to Basco (2016), as an external mechanism of corporate governance, shareholders have an important role in overseeing the company's activities. As a company owner, shareholders have the power to influence the policies that is taken by directors. Therefore, shareholders can reduce risk preferences taken by directors (Basco, 2016). The ownership structure is much more owned by the family as the main controller (Diyanty, 2012) than other ownerships, especially in developing countries (Khan et al., 2015). Ghosh and Tang (2015) noted that 85\% of companies in the world are family companies.

In Indonesia, around $50 \%$ of companies that is listing in Indonesia Stock Exchange (BEI) is a family company (Utami, 2014; Masripah, 2016). Khan et.al. (2015) stated that family shareholders have long-term investment that is characterized by ownership transfer from a generation to other generations. Thus, family shareholders strive to maintain family reputation and avoid risks that could damage family reputation (Chen et.al., 2010). Kim et al. (2014) suggested that family shareholders strive to reduce risk preferences. Therefore, the family shareholders can push the directors to avoid taking too risky policies and endanger the company's sustainability.

The significance of this study is due to the compensation in Indonesia has not been efficient enough compared to the task given for directors (Syakhroza, 2005). This is exacerbated by the disproportionate compensation of directors between companies (Gandy, 2016). In addition, this research is important because the selection of directors is often based on political connections and friendship principles in Indonesia. This is caused by less intensive market for executive jobs. Therefore, it allows for different forms of tournaments between directors in the industry. Furthermore, as an external corporate mechanism, the shareholder structure 
certainly contributes in influencing specifically for family ownership as the most dominant ownership structure in Indonesia (Diyanty, 2012). This research examined the effect of joint effect between compensation gap and company shareholder structure on company policy.

\section{Literature Review}

\subsection{Tournament Theory and Compensation}

The compensation package consists of various components. It can be short term and long term (Eriksen and Kvaloy, 2014). Based on PSAK 7 (2011), the compensation, that is provided to key management members, is divided into five forms: short-term employee benefits (eg salaries, incentives, annual bonuses), post-employment benefits (retirement benefits), termination benefits, Stock options, and other employee benefits. Tournaments theory are currently being attention in assessing the impact of compensation for management (Eriksson, 1999). As a tournament, there will be prizes of tournament to the winner. The prize form of the tournament depends on the form and location of the tournament. Big prize will increase the effort of the participants. According to Coles et al. (2012) this theory presents two forms of tournaments; internal tournaments and external tournaments.

Internal tournament is a competition between directors within a company. The main prize of tournament is a promotion to be CEO, pride, and ability in self-actualization (Kubick and Masli, 2016). In Indonesia, amount of compensation is not disclosed in detail for each board of directors. Disclosure is more often in accumulation. Therefore, research on internal tournaments is difficult to implement in Indonesia. External tournaments are competitions that occur between directors in industry (Huang et al., 2015). This tournament will motivate participants to get prize of tournament in the form of promotion in a company that provides a better compensation package (Kini and Williams, 2012; Kubick and Masli, 2016). Murphy (1999) mentions that promotion to a better company will improve compensation received, prestige, and a sense of pride from the individual. According to Kale et al. (2009), the directors will give more effort as a signal that he is better than other competitors to get the prize.

To show better performance from rivals, the board must be brave to adopt a risk-taking policy. Risk-taking policies are like the two sides of the coin's eye, raises benefits and risks simultaneously (Chen et.al., 2010). Risky policies are chosen because of their belief that risk will result a better performance (Jaisswall and Bhattacharya, 2016). The likelihood of risktaking policy increases while the reward increases (Eriksson, 1999). The rewards will increase if the compensation received by the board of directors has a huge gap with other directors in an industry. It will add desire of the directors in the company to move. The use of industry benchmarks because directors pay attention to their experience and expertise so that the motivation of the directors will be reduced to move to other industries (Kolb, 2010).

\subsection{Ownership Structure and Family Firm}

One of the external mechanisms affecting corporate governance practices is the ownership structure (Diyanty, 2012). The ownership structure is the proportion of ownership by a group of individuals or institutions within the company (Arifin, 2003). The shareholding structure certainly has an important impact on the company's control system (Jaisswall and Bhattacharya, 
2016). Share ownership structure can influence the strategy and decision making taken by management. By type, share ownership can be grouped into managerial, institutional, state, foreign, public, family, and community ownership (Arifin 2003)

In family ownership, type II agency problems appear more often than type I (Khan et al., 2015). By placing family members as top management, shareholders' and management's interests are the same so that type I agency issues are rare (Chau and Leung, 2006). Family members as corporate executives will act in considering the interests of family shareholders, it is not for the benefit of the whole shareholders. Type II agency problem will cause expropriation more frequently. Expropriation may be taking of benefits from affiliate transactions or not distributes dividend (Ali and Lesage, 2014; Diyanty, 2012). In addition, expropriation can be done without sharing dividend (Fan and Wong 2002).

\subsection{Hypothesis Development}

Motivation, effort, and incentives in working depend on the rewards and benefits derived from the job. The greater of rewards and benefits that are expected to be gained then increase the motivation, effort, and incentives of a person in achieving the rewards and benefits (Robbins, 2010). The tournament theory explains the existence of competition between directors in a fight for the rewards and benefits. Internal tournaments present competition among directors within the company (Kini and Williams, 2012) while external tournaments take place between directors within the same industry (Coles et al., 2012)

In the perspective of an internal tournament, the compensation gap between CFOs and company CEOs increases risk taking of corporate CFOs (Erikson and Kvaloy, 2014). The further gap increases tax aggressiveness (Kubick and Masli, 2016), increased capital expenditures, increased R \& D activities, increasing focus on segments, and increased debt in the company's capital structure (Kini and Williams, 2012) and increased likelihood of fraud within the firm (Vergauw et al., 2015).

In the perspective of an external tournament, the directors of the company will give their best effort and performance compared to other directors in the industry to get prizes and benefits from the tournament. To win the tournament, the directors of the company must demonstrate satisfactory performance such as increased corporate profit, asset increase, and positive cash flow (Kubick and Masli, 2016).

To achieve their best performance, directors will not hesitate to take risky policies. The policy, on the one hand, will provide risks and threats while on the other hand, it will provide benefits in the form of better performance. Greater rewards and benefits that is expected by the directors motivate them to increase the probability of choosing such risky policies. Coles et al., (2012) argue that companies with CEO compensation far below the industry average will increase the risk of the company to win the tournament.

Risk preferences can be selected if the circumstances support company. Ross et al. (2010) states that risk preferences are taken with many considerations. Increased debt in companies with high debt-to-asset ratios can increase the risk of bankruptcy so that interest given by investors / banks is also high. Under these conditions, an increase in debt is not an appropriate strategy in meeting the financing needs of the company but by issuing new shares. According 
to Robbins et al. (2010), focus strategy can indeed provide a competitive advantage for the company. However, the focus strategy can undermine the company's market share due to the production of some types of company products that have existed in the previous market. This study considers that compensation is one of the most important tools in the internal governance mechanism of the company. Compensation becomes a vital part in welfare of the board of directors. Therefore, directors still take aggressive policies to provide the best performance for the company. The hypothesis in this study is.

$\mathrm{H}_{1}$ : Industry compensation gap has negative effect on risk preferences

Family firms put attention about long term existence (Basco, 2016). Previous research indicates that more than $50 \%$ of listed companies in Indonesia are dominated by family ownership (PWC, 2014; Diyanty, 2012). The family company strives to maintain the existence of the company so that it can be legacy to the next generation. Family firm is very sensitive regarding company reputation. Therefore, family owners will seek to reduce risky policies that will be threat for survival of the company. The results of the study from Shevlin et al. (2010) states that family firms are not aggressive in terms of tax payments compared to non-family companies. The results are in line with the previous argument that family owners will avoid the risk of litigation related to tax payments and can destroy family reputation. Gomes-Meija et al. (2007) also gave similar results that family firms are more diversified in terms of company products.

On the other hand, risky policies exist in the family enterprise. This happens because family shareholders often point out family members to place ini strategic positions within the company (PWC, 2014). This can be triggers of entrenchment effect, that is a policymaking tendency to enrich the family shareholders (Claessens et al., 2010). This causes the company's wealth is focused on family shareholders and not distributed to all shareholders. Diyanti (2012) found concentrated family ownership have more related party transactions compared to non-family companies. This study utilized capital expenditure as a measurement of director's preference which is not related to the misuse of the company (related party transactions, transfer pricing). policies such as change in capital structure, diversification, and capital expenditures for developing company's business may jeopardize the company's viability. The hypothesis in this study is.

\section{$\mathrm{H}_{2}$ : Family ownership has negative effect on risk preferences}

According to the tournament theory, competition only occurs when there is a motivation from the directors to move to other companies. Furthermore, the board of directors will participate in the competition if they receive additional benefits (compensation). PWC (2014) finds that family shareholders are more likely to vote and keep their family members in the board of directors' position. Directors who come from family members are certainly more motivated to develop the family business because the wealth of family members will increase.

In addition, Combs et al. (2010) mentions that CEO salaries in family firms are $56 \%$ larger than non-family companies. The result was obtained because incentives in family firm aims to prosper the family members (Anderson and Reeb, 2003). Therefore, the motivation to move to other companies will be reduced. 
Family shareholder will supervise the company intensively rather than other forms of ownership because their personal wealth is depending on firm performance (Anderson and Reeb, 2003). Intensive monitoring is conducted to achieve long-term goals. Thus, they will avoid risky policies that could damage family reputation. Therefore, the shareholders of the family firm can pressure the board of directors not to take dangerous policies. The hypothesis in this study is.

$\mathrm{H}_{3}$ : $\quad$ Family ownership weakens the negative effect of industry gap compensation on risk preferences

\section{Research Methodology}

\subsection{Research Model}

This study employed models developed by Kini and Williams (2012) and Kubick and Masli (2016). This study included family ownership variables as independent variables and moderation variables.

Model 1:

Capex $_{i, t}: \quad \beta_{0}+\beta_{1}$ Gap $_{i, t-1}+\beta_{2}$ CEOtenure $_{i, t}+\beta_{3}$ CEOAge $_{i, t}+\beta_{4}$ Size $_{i, t}+\beta_{5}$ MBV $_{i, t}+\beta_{6}$ Sales $_{i, t}$

$$
+\beta_{7} \operatorname{Lev}_{\mathrm{i}, \mathrm{t}}+\beta_{8} \mathrm{ROA}_{\mathrm{i}, \mathrm{t}}+\mathrm{e}
$$

Model 2:

Capex $_{\mathrm{i}, \mathrm{t}} \quad \beta_{0}+\beta_{1}$ Gap $_{\mathrm{i}, \mathrm{t}-1}+\beta_{2}$ Family $_{\mathrm{i}, \mathrm{t}}+\beta_{3} \mathrm{Gap}_{\mathrm{i}, \mathrm{t}}{ }^{*}$ Family $_{\mathrm{i}, \mathrm{t}}+\beta_{4}$ CEOtenure $_{\mathrm{i}, \mathrm{t}}+\beta_{5}$ CEOAge $_{\mathrm{i}, \mathrm{t}}$ $+\beta_{6}$ Size $_{\mathrm{i}, \mathrm{t}}+\beta_{7}$ Tobins $_{\mathrm{i}, \mathrm{t}}+\beta_{8}$ Sales $_{\mathrm{i}, \mathrm{t}}+\beta_{9}$ Booklev $_{\mathrm{i}, \mathrm{t}}+\beta_{10} \mathrm{ROA}_{\mathrm{i}, \mathrm{t}}+\mathrm{e}$

Where:

Capex : Rasio between capital expenditure and company's total assets

Gap : Avaerage compensation in industry minus CEO compensation in company.

Family : : Percentage of family ownership in company

Gap*Family : Interaction between compensation gap and family firm

CEOtenure : CEO tenure

CEOAge : Age of CEO

Size : Logaritma natural total assets

Tobins : Rasio between market value to book value

Sales $\quad:$ Percentage of increasing sales from year $\mathrm{t}$ to year $\mathrm{t}-1$

Booklev : Rasio between long term debt and short term interest bearing to total

assets ROA : Rasio between net income to total asets

\subsection{Variabel Operationalization}

\subsubsection{Industrial Compensation Gap}

The board's compensation iwas measured by the compensation of the CEO. The compensation of the CEO includes salaries, benefits, facilities, honorarium, and tantiem / performance incentives (PSAK 7, 2011). There are difficulties in determining the salary of the CEO in public firm which is listing in IDX because the amount of executive salary is not revealed in detail. Therefore, PER-07/MBU/2010 ministry of BUMN serves as a benchmark. The 
compensation of the CEO can be obtained based on the formula below.

If the company disclose compensation for directors

$$
\text { CEO Compensation }=\frac{\text { Total of whole Compensation }}{\left(0.9\left(N_{x}-1\right)\right)+1}
$$

If the company disclose compensation for directors and commisioners

$$
\text { CEO Compensation }=\frac{\text { Total of whole Compensation }}{1,45+0.9\left(N_{x}-1\right)+0.405\left(N_{y}-1\right)}
$$

where:

$\mathrm{N}_{\mathrm{x}} \quad$ : number of director

$\mathrm{N}_{\mathrm{y}}^{\mathrm{x}}$ : number of commissioner

This study clasifies the industry of companies as much as 9 industries in according Fact Book BEI year 2016. The determination of the compensation gap of Chief Executive Officer in industry refers to research conducted by Coles, Li, and Wang (2012) with a ratio of CEO compensation in company with average compensation in industry

\subsubsection{Family Ownership}

In this study, the nature of the family firm was determined by using dummy variables. The Family Variables were assigned a value of 1 (one) when the company belongs to the category of the company with the final family control and 0 (zero) when the company is not a family (Diyanty, 2007). A company is categorized as a family company when the number of stock belonging to the owner of the family has the largest portion. The determination of shares belonging to the family owner is built on the definition in Arifin's (2003) study, which conceals the definitions used by La Porta et al. (1999) and Claessens et al. (2000), ie all individuals or corporations it supports (ownership $>5 \%$ ) except public companies (tbk) listed on IDX, state, financial institutions, mutual funds, insurance, pension funds, banks and cooperatives), foreign and public (Individuals not required). In this case, it is the responsibility of the company, it will be directly treated as the owner of the family, whether it is a public company (tbk.) And financial institutions, mutual funds, insurance, pension funds, banks and cooperatives.

\subsubsection{Capital Expenditure}

Capital expenditure is the amount of corporate spending for expansion purposes. The real form of capital expenditure can usually be seen from the increase in total assets of the company. Measurement of capital expenditures refers to research conducted by Kale et al. (2009) that use ratio between capital expenditures with total shares outstanding.

\subsubsection{Control Variable}

Yermack (2007) states that age reflects the level of experience and management conservatism. The experience of directors will increase with age. Furthermore, older directors are more careful and thoughtful. Therefore, Coles et al. (2012) considers that age has negative effects on risk-taking policies. Age will be measured by age of the CEO in year $t$. 
Kini and Williams (2012) and Coles et al. (2009) argue that tenure of directors has a positive influence on the possibilities of risk preferences. It happens due to in the end of directors' position, there will be another company that recruite them.

Kini dan Williams (2012) dan Coles et al. (2012) argues that firm size positively affects to risky policies. This may happen when large companies try to maintain its existence in the competition so they are forced to innovate continiously in business line. The size of the company is measured from the natural logarithm of total assets.

Haß et al. (2015) argue that corporate value has a negative effect on the possibility of risktaking policies. The company will try to avoid the risk that may occur if the policy fails. The market will respond the failure with declining in corporate value. Measurement of company value refers to the research of Kini dan Williams (2012). Company value is measured from the value of Tobins' $Q$

Kini and Williams (2012) argue that sales growth positively affects the possibility of risktaking preferences. The company wants to maintain and increase its sales growth by adding debt, focusing on one segment, and further intensifying capital expenditure. The measurement of sales growth refers to Coles et al. (2009) that use the percentage of increase in sales in year t compared to Year $\mathrm{t}-1$.

Leverage measures the amount of assets that is funded by debt. Companies that have leverage ratio is more cautious in taking risky policies (Shaohua, 2010). Leverage ratio is measured based on Coles et al. (2009) from the ratio of long-term debt and short-term debt to total assets. Increasing in risk because of adding debt will increase the chances of financial distress. Leverage ratio is measured based on Kini dan Williams (2012) that obtained from long termdebt ratio and short term debt to total assets. Increasing of corporate debt is measured by the difference between Dlevt and Dlevt-1

The profitability of a company measures how much profit that a company generates from the use of company assets. Ross et al. (2010) explains that firms should adopt risk preferences when companies are in profit and avoid risk preferences when they are in lose.

\subsection{Sample and Population}

The population in this study is a company who listed in Indonesia Stock Exchange (BEI) in 2011-2015. Year 2011 as the initial year due to PSAK 7 which regulates the disclosure was implemented in 2011. Sample selection uses purposive sampling method. The financial and banking industries are excluded from the population because they are highly regulated. Some regulations can affect the company policies directly and indirectly. Samples are expected to have necessary information and data, including the amount of management compensation. Furthermore, this study excludes companies with negative equity because the company has financial difficulties. Policy taking tends to be different from other companies. 
Table 1. Sample Selection

\begin{tabular}{lllllll}
\hline Year & $\mathbf{2 0 1 1}$ & $\mathbf{2 0 1 2}$ & $\mathbf{2 0 1 3}$ & $\mathbf{2 0 1 4}$ & $\mathbf{2 0 1 5}$ & Total \\
\hline Total company based on Fact Book BEI -2015 & 436 & 458 & 479 & 491 & 511 & 2375 \\
\hline Financial industry & -72 & -74 & -79 & -85 & -87 & -397 \\
\hline Does not report the compensation management & -82 & -68 & -40 & -46 & -90 & -326 \\
\hline Financial year ending other than 31 December 2017 & -1 & -1 & -1 & -1 & -1 & -5 \\
\hline Has negative equity & -16 & -15 & -14 & -18 & -20 & -82 \\
\hline Data not obtained for all research variables & -41 & -44 & -65 & -66 & -65 & -281 \\
\hline Total Observation & $\mathbf{2 3 4}$ & $\mathbf{2 6 5}$ & $\mathbf{2 8 9}$ & $\mathbf{2 8 4}$ & $\mathbf{2 5 7}$ & $\mathbf{1 2 8 2}$ \\
\hline Source: Processed data (2017) & & & & & &
\end{tabular}

Table 2. Descriptive Statistic

\begin{tabular}{|c|c|c|c|c|c|}
\hline Variable & Mean & Median & SD & Min & Max \\
\hline Gap & 0.944 & 0.606 & 1.024 & 0.051 & 4.928 \\
\hline Capex & 0.050 & 0.021 & 0.057 & 0.001 & 0.333 \\
\hline Age & 52.677 & 52 & 8.801 & 30 & 86 \\
\hline Tenure & 7.354 & 4 & 8.453 & 0 & 46 \\
\hline \multirow[t]{2}{*}{ Total Asset } & 7.478 & & 14.406 & 10.276 & 166.17 \\
\hline & Trillion & & Trillion & Billion & Trillion \\
\hline MBV & 2.262 & 1.383 & 2.286 & 0.047 & 10.91 \\
\hline Sales & 0.165 & 0.109 & 0.397 & -1 & 1.9 \\
\hline Lev & 0.141 & 0.097 & 0.148 & 0 & 0.791 \\
\hline ROA & 0.076 & 0.058 & 0.135 & -1.4 & 1.626 \\
\hline Variable & \multicolumn{2}{|c|}{ Dummy $=0$} & \multicolumn{2}{|c|}{ Dummy $=1$} & Total \\
\hline Family & \multicolumn{2}{|l|}{$56,6 \%$} & \multicolumn{2}{|l|}{$43,4 \%$} & $100 \%$ \\
\hline \multicolumn{6}{|c|}{$\begin{array}{l}\text { Gap: compensation ratio of the president director with the average compensation of the chief } \\
\text { director in the industry; Family: dummy variable, } 1 \text { if the company is owned and controlled by the } \\
\text { family; FamilyGap: Gap and Family interaction variables; Capex: capital expenditure to total asset; } \\
\text { Age: age of the president director; Tenure: term of office; Size: natural logarithm of total assets; } \\
\text { MBV: market-to-book ratio; Sales: Increase on sales from year t-1 to year t; Lev: long term debt + } \\
\text { short term bearing debt to total assets ratio; ROA: dividing net income by average total assets }\end{array}$} \\
\hline
\end{tabular}

\section{Results and Analysis}

\subsection{Descriptive statistic}

Descriptive statistics provide an overview of variable characteristics to be tested. Table 2 displays a statistical description after the winsorization is performed. The average value of the industrial compensation gap is 3.116 billion for each year. The value is 17 times lower than the average CEO compensation rate in the US that reaches 55 billion per year (Coles, Li, and Wang, 2013). The average Gap score is below 1 in Table 2 shows that most firms have compensation below the industry average. 56.7\% of companies listed on IDX during 2011 and 2015 are owned and controlled by the family. The results are consistent with research conducted by Diyanty (2007) which found that the majority of companies in Indonesia are owned and controlled by the family ownership.

The company that has a small CAPEX value 0.051 because the company only issued capital expenditures for maintenance activities rather than purchase or investment of new fixed assets. 
Table 3. Model Regression

\begin{tabular}{|c|c|c|c|c|c|c|c|}
\hline \multirow[t]{2}{*}{ Variable } & \multirow[t]{2}{*}{ Eks } & \multicolumn{3}{|c|}{ Model 1} & \multicolumn{3}{|c|}{ Model 2} \\
\hline & & Coef & Prob & & Coef & Prob & \\
\hline Constant & & 0.064 & 0.000 & $* * *$ & 0.076 & 0.000 & *** \\
\hline Gap & - & -0.007 & 0.002 & $* * *$ & -0.006 & 0.041 & $* *$ \\
\hline Family & - & & & & -0.018 & 0.005 & $* * *$ \\
\hline GapFamily & + & & & & -0.001 & 0.391 & \\
\hline Age & - & -0.001 & 0.089 & $*$ & -0.001 & 0.050 & $* *$ \\
\hline CEOtenure & - & 0.001 & 0.157 & & 0.001 & 0.064 & \\
\hline Size & $+/-$ & -0.002 & 0.115 & & -0.003 & 0.066 & $* * *$ \\
\hline MBV & + & 0.002 & 0.050 & $* *$ & 0.001 & 0.052 & $* *$ \\
\hline Sales & + & -0.008 & 0.016 & $* *$ & -0.008 & 0.020 & $* *$ \\
\hline Lev & - & 0.054 & 0.000 & $* * *$ & 0.060 & 0.000 & $* * *$ \\
\hline ROA & + & 0.001 & 0.462 & & -0.002 & 0.436 & \\
\hline Adjusted R2 & & & 0.031 & & & 0.063 & \\
\hline F-Statistic & & & 0.000 & & & 0.000 & \\
\hline \multicolumn{8}{|c|}{$* * *$ significant $1 \%$.** significant $5 \%, *$ significant $10 \%$} \\
\hline \multicolumn{8}{|c|}{$\begin{array}{l}\text { Annotation } \\
\text { Gap: compensation ratio of the president director with the average compensation of the chief director in the industry; Family: } \\
\text { dummy variable, } 1 \text { if the company is owned and controlled by the family; FamilyGap: Gap and Family interaction variables; } \\
\text { Capex: capital expenditure to total asset; Age: age of the president director; Tenure: term of office; Size: natural logarithm of } \\
\text { total assets; MBV: market-to-book ratio; Sales: Increase on sales from year t-1 to year t; Lev: long term debt + short term } \\
\text { bearing debt to total assets ratio; ROA: dividing net income by average total assets }\end{array}$} \\
\hline
\end{tabular}

The age of the main directors who rule the BEI company varies from 30-86 years. The range indicates that age is not a single factor in electing CEO. The standard deviation value of total assets is very high and suggest that there are imbalances of firm size in Indonesia. The average value of MBV is above 1. It indicates that market reaction to the existing companies in Indonesia is good. The average value of LEV is relatively small and it shows that firms in IDX are more interested in issuing new shares than by choosing long-term debt as a source of financing. The ROA variable describes the profitability of a company. In the sample company, the average profitability of $7.6 \%$. It shows that companies in Indonesia are quite healthy in terms of financial.

\subsection{Results}

\subsubsection{The effect of industry compensation gap on risk risk preferences}

The research model 1 examined the effect of the compensation gap of the CEO in an industry on the risk preference of the directors. The Stata results in table 3 (model 1) show that the GAP variable has a negative effect on the CAPEX variable. Result shows that industrial compensation gap negatively affects risk preference of directors. This result is consistent with the hypothesis that the greater compensation gap negatively affects risk preferences.

This study supports Kini and Williams (2015), Kubick and Masli (2017) and Coles et al. (2006). Based on the theory of the tournament, many people will compete because of the motivation in reciting the tournament prize. The winners of the tournament are those who provide better business and performance than their competitors. Directors often take policies that contain elements of risk to provide better performance in competition. According to Kini and Williams (2015), in the case of tournaments in industry, the prizes are better compensation. The further of 
compensation gap of the board of directors with standard compensation in industry, the greater of prize that is contested. Implication of the theory mention that the amount of tournament prizes is different for each board of directors.

Coles et al. (2006) argue that a director pays attention to the amount of compensation that will be received. The greater of compensation that can be obtained, the greater of effort. If the board of directors sees that the amount of compensation received does not match to the expectation, there is intention to move to a company that offers a better compensation package. This desire cannot be realized immediately because many directors of other companies are willing to occupy that position. In line with theory of the tournament, the best performing directors will occupy that position. Therefore, the directors of the company take aggressive strategy and contains risks to give good results as they expected. Based on the results of hypothesis testing and data analysis that was performed, hypothesis 1 in this study is accepted.

\subsubsection{The effect of ultimate family ownership on risk preferences}

The research Model 2 examined the effect of ultimate-family ownership on risk preferences. The stata results in Table 3 (Model 2) show that the FAMILY variable has a negative effect only on the CAPEX as dependent variable. Based on the results of these tests show that if the company owned and controlled by the family, the smaller preference of directors against the risk. The results of this study support the research that has been done by Basco (2016), Shevlin et al. (2010), and Gomes-Meija et al. (2007).

Family firms have specific attention in the long term of company (Basco, 2016). The family company strives to maintain the company's existence in the long run to continue its ownership to the next generation. Family firm is very sensitive related reputation. Therefore, family owners will seek to reduce policies that will pose a risk to the survival of the company. The results support the argument that family firms prefer to be conservative and play within a safe zone. Based on the results of hypothesis testing and data analysis that was conducted, hypothesis 2 in this study can be accepted

4.2.3. The effect of interaction of industry compensation gap and ultimate family ownership on risk risk preferences

Model 2 ofTable 3 was used to examine the effect of interaction between industrial compensation gap and the ultimate ownership of the family on the risk preference of the directors. The Stata results in table 3 (model 2) show that the GAPFAMILY variable has no effect on CAPEX variable. The results in Table 4 show that if the FAMILY and GAPFAMILY variables are included in the model, the GAP variable's significance effect becomes weakened. In model 1, the GAP variable had a significant negative effect at $1 \%$ significance level, while in model 2, the GAP variable had no effect on the CAPEX variable. Based on the results of the tests, there is no empirical evidence that the ultimate ownership of the family undermines the significant negative influence of the compensation gap (above industry) on the risk preference of the board of directors.

This result does not support a research conducted by PWC (2014) that there is no tournament in the company owned by the family. Combs et al. (2010) mentions that CEO salaries in family firms are $56 \%$ larger than non-family companies. The results are obtained because of 
the incentives owned by the family owners to prosper the family members (Anderson and Reeb, 2003). Therefore, motivation of CEO in family firm to move to another company will decrease. In addition, the family shareholders have more intensive supervision than other forms of ownership (Anderson and Reeb, 2003). Personal wealth depends on company performance. Furthermore, intensive supervision is conducted to ensure long-term goals can be accomplished with avoid risk preferences that can damage family reputation.

The insignificant effect might be happened due to the presence of several directors in the family firm who still want to join the tournament, thus, they do not decrease the risk preferences. The tournament can be a competition among family members to be CEO in the best company owned by their family. Based on the results of hypothesis testing and data analysis was performed, then hypothesis 3 in this study is not accepted

\section{Conclusion, Suggestion, and Implication}

\subsection{Conclusion}

Based on the results of hypothesis testing provide empirical evidence that the industrial compensation gap negatively affects the risk preference. This study also provides empirical evidence that family ownership negatively affects risk preference. The results of this study do not provide empirical evidence that family owners weaken the negative effects of industrial compensation gaps on risk preference. Which means, the owner of the family firm cannot hold director's motivation in taking aggressive strategy when directors have low compensation (under average industry).

\subsection{Suggestion}

The ownership of foreign company as a controlling shareholder cannot be traced until the individual ownership may have affiliation relationship with the controlling shareholder within the country. Thus, further research can trace foreign companies as the controlling shareholder. This study uses only one type of industrial compensation gap measurement. Coles et al. (2006) have provided several types of compensatory gap measurements. Future research may use some measurements that may be able to produce different results.

\subsection{Implication}

The results of the study found that the provision of compensation has not been efficient in Indonesia. This study is expected to encourage regulators to establish a special regulation regarding details of directors' compensation. In addition, the study also found that noncompliance with SFAS 7 concerning disclosure of transactions to related parties. Regulators need to reinforce regulations requiring disclosure of management compensation because it contains important information. This study found that shareholder structure influenced the policy making in the company. This study is expected to encourage regulators to require disclosure of the ownership chain of the company to the final owner 


\section{References}

Anderson, R., Reeb, D.,2003. Founding-family ownership and firm p erformance: evidence from the S\&P 500. Journal of Finance 58, 1301-1328.

Arifin, Z .,2003. Agency problem and control mechanism on family firm in Indonesia. Unpublished Dissertation. Universitas Indonesia.

Basco, Rodrigo.,2016. Where do you want to take your family firm? A theoretical and empirical exploratory study of family business goals. Bussiness Research Quarterly.

Bognanno, M.L.,2001. Corporate tournaments. J. Labor Econ. 19 (2), 290-315.

Chen, S., Chen, X., Cheng, Q., Shevlin, T.,2010. Are family firms more tax aggressive than non-family firms. Journal of Financial Economics.

Chrisman, James J., Jess H. Chua, and Pramodita Sharma. 2005. Trends and Directions in the Development of a Strategic Management Theory of the Family Firm. Entrepreneurship Theory and Practice

Claessens, S., S. Djankov, J. Fan,L. Lang,2002. Disentangling the incentive and entrenchment effects of large shareholdings. Journal of Finance 57, 2741-2771

Coles, J., Daniel, N., Naveen, L.,2006. Managerial incentives and risk-taking. Journal of Financial Economics. 79, 431-468.

Coles J.L., Li Zhichuan, Wang Yan.,2012. Industy Tournament Incentives. Unpublished paper.

Diyanty, V.,2012. Effect of Ultimate Shareholder on Affiliate Transaction and Income quality. Unpublished Dissertation. Universitas Indonesia.

Eriksson, Tor.,1999. Executive Compensation and Tournament Theory: Empirical Tests on Danish Data. Journal of Labor Economics , 17(2), pp. 262-80.

Eriksen, Kristoffer W., Kvaloy Ola.,2014. Myopic Risk-Taking Tournament. Journal of Economic Behavior \& Organization., 97, 37-46

Haß, Lars Helge. Maximilian A. Müller, Skrålan Vergauwe. Tournament incentives and corporate fraud. Journal of Corporate Finance 34 (2015) 251-267

Indonesia Stock Exchange.,2016. IDX fact book. 2016

Jaiswall, S.S., Bhattacharyya, A.K.,2016. Corporate governance and CEO compensation in Indian firms. Journal of Conemporary Accounting and Economics.

Jian Huang, Bharat A. Jain, Omesh Kini,2015. Industry Tournament Incentives and the Strategic Value of Corporate Liquidity. Unpublished Paper. 
Kale, J.R., Reis, E., Venkateswaran, A.,2009. Rank-order tournaments and incentive alignment: the effect on firm performance. Journal of Finance 64, 1479-1512.

Khan, Arifur. Muttakin, M.B., Siddiqui. J.,2015. Audit fees, auditor choice and stakeholder influence: Evidence from a family-firm dominated economy. The British Accounting Review (47), p 304-320

Kini, O., Williams, R.,2012. Tournament incentives, firm risk, and corporate policies. $J$. Financ. Econ. 103 (2),350-376.

Komite Nasional Kebijakan Governance.,2006. Pedoman Umum Good Corporate Governance Indonesia. Jakarta

Kolb, R.W.,2010. Corporate governance: a synthesis of theory, research, and practice. Wiley.

Kubick T.R., A.N.S. Masli.,2016. Firm-level tournament incentives and corporate tax aggressiveness. Journal of Accounting and Public Policy 35. 66-83

Murphy, K.J.,1999. Executive compensation. Handbook of labor economics 3, 2485-2563.

PwC.,2014. Survey Bisnis Keluarga Indonesia. Website. 1 Jan. 2016.

Pernyataan Standar Akuntansi Keuangan Nomor 7., 2011. IAI.

Robbins, Stephen P. Organizational behavior: concepts, controversies, and applications. 2010 Englewood Cliffs:. Prentice-Hall,. 14 ed

Syakhroza, Ahmad.,2005. Corporate Governance:History, Theory, Model, and Governane System Professor Inauguration. Universitas Indonesia. 